\title{
Survey for Viruses of Grapevine in Oregon and Washington
}

R. R. Martin, Horticultural Crops Research Lab, USDA-ARS, Corvallis, WA 97330; K. C. Eastwell, Department of Plant Pathology, Washington State University, Prosser 99350; A. Wagner, Washington State Department of Agriculture, Olympia 98501; S. Lamprecht, Horticultural Crops Research Lab, USDA-ARS, Corvallis 97330; and I. E. Tzanetakis, Department of Botany and Plant Pathology, Oregon State University, Corvallis 97331

\begin{abstract}
Martin, R. R., Eastwell, K. C., Wagner, A., Lamprecht, S., and Tzanetakis, I. E. 2005. Survey for viruses of grapevine in Oregon and Washington. Plant Dis. 89:763-766.

Grapevines (Vitis spp.) in Washington and Oregon were surveyed for the prevalence of key grapevine viruses. Samples collected from 1,522 vines in Washington were tested for Rupestris stem pitting associated virus (RSPaV), Grapevine fanleaf virus (GFLV), Arabis mosaic virus (ArMV), Tomato ringspot virus (ToRSV), and Grapevine leafroll associated virus-3 (GLRaV-3). Tests were also conducted for GLRaV-1 and -2 on 420 samples from Washington. Two hundred forty samples collected from wine grape vineyards in Oregon were tested for GLRaV-1, -2 , and -3 , and an additional 2,880 samples were collected from 40 vineyards known to have high populations of Xiphinema americanum nematodes. The latter were tested for ArMV, ToRSV, and GFLV. GLRaV-1, -2 , and -3 were detected in $2.6,0.2$, and $6.5 \%$ of the Washington samples and in $3.0,0.4$, and $4.4 \%$ of the Oregon samples. RSPaV was detected in $4.6 \%$ of the samples from Washington. No ToRSV, ArMV, or GFLV was detected in any of the samples from Oregon or Washington. Transmission of field isolates of GLRaV-3 from Washington by the grape mealybug also was demonstrated.
\end{abstract}

There are approximately 50,000 acres (20,250 hectares) of grape (Vitis spp.) production in Washington, which is divided approximately equally between wine and juice grapes (13). The production is concentrated in Benton, Yakima, and Grant counties east of the Cascade Mountains, with smaller acreages planted throughout Washington. The primary wine grapes grown in Washington are Chardonnay, Merlot, Cabernet Sauvignon, and White Riesling. In Oregon, there are approximately 10,000 acres $(4,050$ hectares) of grapes grown almost exclusively for wine production. The production is divided between the Willamette Valley where Pinot Noir, Pinot Gris, Riesling, and Chardonnay are the major cultivars and southern Oregon where Cabernet Sauvignon, Merlot, and Chardonnay are the primary cultivars. Wine production in both states is increasing in volume and value with a concomitant increase in acreage planted.

There were several reasons to undertake a survey of viruses in grapevines at this time. Much of the planting stock for Washington and Oregon vineyards is produced

Corresponding author: R. R. Martin

E-mail: martinrr@science.oregonstate.edu

Accepted for publication 15 March 2005.

\section{DOI: 10.1094/PD-89-0763}

This article is in the public domain and not copyrightable. It may be freely reprinted with customary crediting of the source. The American Phytopathological Society, 2005. in California. In January 2001, Rupestris stem pitting associated virus (RSPaV) was eliminated from the California Grapevine Registration and Certification program. Consequently, certified planting material from California was no longer accessible to the Washington State industry, where $\mathrm{RSPaV}$ remained on the state's list of quarantine pests. Oregon and British Columbia have not regulated this virus for many years. Secondly, the impending changes of grapevine nursery stock phytosanitary requirements for international trade that will occur with the adoption of the NAPPO (North American Plant Protection Organization) grapevine standard may require information on distribution of viruses if plant movement is restricted due to virus status. The NAPPO grapevine standard sets new phytosanitary requirements for trade between the United States and its NAFTA trading partners, Canada and Mexico, since it recognizes quarantines of A-1 pests, i.e., pests that are not known to occur in the country or an area within the country, and does not recognize state quarantines. NAPPO standards include a provision that justifies stricter requirements than those set at the national level: if a pest is shown not to occur in an area or is known to occur but is officially controlled, the area may be designated a "pest free area" (PFA). However, documentation that shows that the pest in question does not occur or is officially controlled is needed. This is accomplished generally through detection or delimiting surveys. Thus, Washington was interested in evaluating the status of RSPaV in its vineyards to determine if it could qualify as a PFA within NAPPO.

In 2000, the Washington Wine Advisory Board supported a project to determine if $\mathrm{RSPaV}$ was present in the Washington grape growing areas. It is more efficient and beneficial to test for multiple viruses at the same time, and additional information obtained on the incidence of a number of viruses would provide the basis for future decisions on their management. A similar survey carried out in Oregon was supported by the Oregon Wine Advisory Board.

In addition to RSPaV, tests for the following viruses were included for the reasons outlined. Grapevine fanleaf virus (GFLV) and Arabis mosaic virus (ArMV) were included in the study because they had been reported recently in Canada (6). The vector of Tomato ringspot virus (ToRSV), the nematode Xiphinema americanum, is common in Oregon vineyards (J. N. Pinkerton, personal communication), and this virus is a problem in raspberry plantings in the Willamette Valley that are in close proximity to many of the Oregon vineyards; therefore, ToRSV was also included in the virus survey. Samples were selected on a random basis with the exception of testing for nepoviruses in Oregon, where 40 vineyards with high numbers of $X$. americanum were selected for more intensive sampling. Grapevine leafroll associated viruses-1, -2 , and -3 (GLRaV) were included since symptoms of leafroll disease had been observed in a number of vineyards in Oregon and Washington. Field observations suggested that the incidence of leafroll disease was increasing. The grape mealybug is the dominant mealybug species in vineyards in Washington (D. James, personal communication).

The objectives of this research were to determine the incidence of the viruses mentioned above in vineyards in Oregon and Washington and to investigate the possibility that the grape mealybug ( $\mathrm{Pseu}$ dococcus maritimus (Ehrhorn)) was vectoring GLRaV-3 in Washington vineyards.

\section{MATERIALS AND METHODS}

Sample collection. In Washington, samples were collected randomly to represent the acreage of grapes grown in the state. To obtain results with a $95 \%$ confidence of estimating the true proportion of 
the population that was infected, 1,522 grape plants were sampled (4). Juice and wine grapes were sampled randomly on an acreage basis; and each selected acre was cross-referenced to the grower. Participation was voluntary, and growers could opt out of the survey. Individual plants were collected by dividing the acreage into quadrants and making selections from within each quadrant on a rotating basis. Since Washington vineyards tend to be large, sampled vines were identified using a geographical positioning system (GPS) so that the same vines could be sampled during multiple collections. In Oregon, sampling sites were identified by vineyard, row, and plant number, and samples were collected to randomly represent the grape acreage, with each sample representing about 40 acres (16 hectares). Additionally, more intensive sampling of 72 vines per vineyard was used for 40 vineyards in Oregon that were known to have high numbers of $X$. americanum, the vector of ToRSV. These vines were tested for ToRSV, ArMV, and GFLV.

Detection of GLRaVs and RSPaV. Samples were collected from September through November. Samples from Washington were tested for RSPaV and GLRaV$1,-2$, and -3 , and the samples from Oregon were not tested for RSPaV since this is not a controlled virus in Oregon. Each sample consisted of either three older leaves or three cuttings, each about the size of a pencil. Tissue for analysis by reverse transcription-polymerase chain reaction (RTPCR) was stored at $-20^{\circ} \mathrm{C}$ until testing. Sections of each of the three leaf petioles, or inner bark tissue from each of the three cuttings, were used as the tissue source for extraction of RNA, and the total amount of tissue per sample was approximately 100 mg. RNA was extracted as described previously (10). Five microliters of the extract was used as the source of RNA template for RT reactions. RT was performed using Superscript II (Invitrogen, Carlsbad, CA) according to the manufacturer's protocol with $0.3 \mu \mathrm{g}$ of random hexameric nucleotide primers (Invitrogen) in a total volume of $50 \mu \mathrm{l}$.

The citation and sequence of the primers, annealing temperatures, and expected amplicons sizes for PCR are given in Table 1. Five microliters of the RT reaction was added to each PCR reaction, Taq polymerase (Invitrogen) was used for the amplification. The program for PCR consisted of $5 \mathrm{~min}$ at $94^{\circ} \mathrm{C}$, followed by 35 cycles of $94^{\circ} \mathrm{C}$ for $1 \mathrm{~min}$, annealing temperature of primer pair (Table 1) for $1 \mathrm{~min}$, and $72^{\circ} \mathrm{C}$ for $2 \mathrm{~min}$. This was followed by a final extension for $10 \mathrm{~min}$ at $72^{\circ} \mathrm{C}$. Amplicons were separated on $2 \%$ agarose gels, stained with ethidium bromide $(100 \mathrm{ng} / \mathrm{ml})$, and visualized with a UV-light. Controls were obtained from Foundation Plant Services at UC-Davis, CA.

Detection of ToRSV, GFLV, and ArMV. Samples were collected in late spring and early summer, and young leaves were used. Samples from Washington were assayed at the WSU ELISA Testing Laboratory at Prosser. Samples were homogenized in grinding buffer $(0.1 \mathrm{M}$ carbonate, $\mathrm{pH} 9.6$, containing $0.05 \%$ Tween $20,0.2 \%$ nonfat milk powder, and $2 \%$ polyvinylpyrrolidone (PVP) in grinding bags $(0.5 \mathrm{~g}$ sample per $5 \mathrm{ml}$ buffer). Samples were tested by double-antibody sandwich enzyme-linked immunosorbent assay (DASELISA) for GFLV, ArMV, ToRSVChickadee strain (BioReba, Reinach, Switzerland), and ToRSV (Agdia, Elkhart, IN) according to the manufacturer's recommendations. Samples from Oregon were tested at the USDA-ARS-HCRL in Corvallis. Tissue was homogenized in grinding buffer with a Pollahne tissue grinder. DASELISA (1) was used for ToRSV and GFLV, while triple-antibody sandwich (TAS) ELISA (1) was used for ArMV detection. In the latter case, the monoclonal antibody (P. Ellis, Phytocultures Ltd., Saanich, BC) and the goat anti-mouse alkaline phosphatase conjugate (Sigma Chemical Co., St. Louis, MO) were added in the same step.

The positive-negative threshold was established at an absorbance value three times the value of negative control grape samples, which ranged from zero to an optical density of 0.10 . RT-PCR conditions were similar to those described above for GLRaV, using primers described in Table 1. Controls were obtained from FPS at UC-Davis.

Transmission of GLRaV-3. In August 2002, second generation instars of grape mealybug were used to transmit virus from naturally infected vines in commercial vineyards. Grape mealybug colonies were located and the host vines tested for the presence of leafrollassociated viruses by ELISA (BioReba). Young instar grape mealybugs were collected from vines that tested negative by ELISA and were placed in organza sleeve cages on young 'Merlot' vines infected with GLRaV-3. After 21 days, the mealybugs were collected and transferred to virus-free, potted vines. They were allowed to colonize the new plants in sleeve cages until a killing frost defoliated the vines 42 days later.

In a parallel experiment, mealybugs that had colonized a virus-infected vine (positive for GLRaV-3 by ELISA) in a commercial vineyard were collected and transferred to virus-free potted vines. The mealybugs were contained in organza sleeve cages until the canes were defoliated naturally 53 days later. All canes were maintained in a shade house, and the recipient vines were assayed by ELISA in August 2003.

Table 1. Primer names, sequence, annealing temperatures, and expected amplicon sizes used in this study for detection of seven viruses in grapevine samples from Washington and Oregon

\begin{tabular}{|c|c|c|c|c|c|}
\hline Virus $^{\mathbf{a}}$ & Primer name & Sequence $\left(5^{\prime}-3^{\prime}\right)$ & Anneal temp (C) & Size (bp) & Ref \\
\hline \multirow[t]{2}{*}{$\mathrm{RSPaV}$} & RSP 48F & AGCTGGGATTATAAGGGAGGT & 55 & 330 & 9 \\
\hline & RSP 49R & CCAGCCGTTCCACCACTAAT & & & \\
\hline \multirow[t]{2}{*}{ GLRaV-1 } & LR-1F & CGACCCCTTTATTGTTTGAGTATG & 55 & 401 & 3 \\
\hline & LR-1R & GTTACGGCCCTTTGTTTATTATGG & & & \\
\hline \multirow[t]{2}{*}{ GLRaV-2 } & LR-2F & ATAATTCGGCGTACATCCCCACTT & 55 & 332 & 15 \\
\hline & LR-2R & GCCCTCCGCGCAACTAATGACAG & & & \\
\hline \multirow[t]{2}{*}{ GLRaV-3 } & LC1-F & CGCTAGGGCTGTGGAAGTATT & 56 & 546 & 5 \\
\hline & LC2-R & GTTGTCCCGGGTACCAGATAT & & & \\
\hline \multirow[t]{2}{*}{ ArMV } & ArMv819 & CACCGCTGGAATTGTAATGC & 52 & 579 & This study ${ }^{b}$ \\
\hline & ArMc1397 & TTGACCACACCACCAATACC & & & \\
\hline \multirow[t]{2}{*}{ ToRSV } & GYVv4483 & GTTCCTGCGGAAGCTGATTG & 51 & 668 & This study ${ }^{\mathrm{c}}$ \\
\hline & GYVc5150 & GGCCACTCATAC $\underline{\text { TCCAGTC }}$ & & & \\
\hline \multirow[t]{2}{*}{ GFLV } & GFLV-V1-F & ACCGGATTGACGTGGGTGAT & 54 & 328 & 11 \\
\hline & GFLV-C1-R & GGTTTCAACCAAAGGGTTCT & & & \\
\hline
\end{tabular}

\footnotetext{
${ }^{\mathrm{a}} \mathrm{RSPaV}=$ Rupestris stem pitting associated virus, $\mathrm{GLRaV}=$ Grapevine leafroll associated viruses, ArMV $=$ Arabis mosaic virus, $\mathrm{ToRSV}=$ Tomato ringspot virus, and GFLV = Grapevine fanleaf virus.

${ }^{b}$ Primers designed in this study with Primer3 (12). Primers based on CP consensus sequences of GenBank accessions D12477, AF135414, AF135413, AF135411, and AF135412. Divergent nucleotides occur at positions indicated with bold/underline. Mismatches at these positions reduce the annealing temperature by $5^{\circ} \mathrm{C}$, compensated by the annealing temperature given in the table.

${ }^{c}$ Designed in this study with Primer3 (12) from GenBank accession 221017.
} 


\section{RESULTS AND DISCUSSION}

$\mathrm{RSPaV}$ was detected in $4.6 \%$ of the vines sampled in this survey (Table 2). This is the first confirmed report of the occurrence of RSPaV in Washington. The result of this survey was a major factor in the subsequent decision to remove RSPaV from the list of quarantine pests in Washington State, although it is still a controlled pest in the state certification program. In addition to the field survey, all accessions in the Washington State Grape Foundation Block were evaluated for the incidence of RSPaV by RT-PCR using the procedures described herein. Of the 92 accessions in the block at the time of the survey, RSPaV was detected in 10 accessions. All vines of these accessions were removed promptly from the foundation block and destroyed. Only one accession of this infected material had been distributed to certified nurseries. Because of this very limited distribution, RSPaV was retained as a controlled pest in the Washington State certification program.

Prior to this study, no data were available for the incidence of nematodetransmitted viruses in vineyards of the Pacific Northwest. The three nepoviruses assayed in this study, ArMV, GFLV, and ToRSV, were not detected in any sample (Table 2), although a number of samples did exhibit elevated absorbance values (up to 2 times the negative control values).

Table 2. Results of grapevine virus testing from Oregon and Washington

\begin{tabular}{llccl}
\hline & & & \multicolumn{2}{c}{ Positive samples } \\
\cline { 4 - 5 } Virus $^{\mathbf{a}}$ & Location & Samples tested & Number & $\%$ \\
\hline RSPaV & Washington & 1,522 & 70 & 4.6 \\
ArMV & Washington & 1,522 & 0 & 0 \\
& Oregon & 2,880 & 0 & 0 \\
ToRSV & Washington & 1,522 & 0 & 0 \\
& Oregon & 2,880 & 0 & 0 \\
GFLV & Washington & 1,522 & 0 & 0 \\
& Oregon & 2,880 & 0 & 0 \\
GLRaV-1 & Washington & 420 & 10 & 2.4 \\
GLRaV-2 & Oregon & 240 & 7 & 2.9 \\
& Washington & 420 & 1 & 0.2 \\
GLRaV-3 & Oregon & 240 & 1 & 0.4 \\
& Washington & 1,522 & 99 & 6.5 \\
& Oregon & 240 & 11 & 4.6 \\
\hline
\end{tabular}

${ }^{\mathrm{a}} \mathrm{RSPaV}=$ Rupestris stem pitting associated virus, ArMV = Arabis mosaic virus, ToRSV = Tomato ringspot virus, $\mathrm{GFLV}=$ Grapevine fanleaf virus, $\mathrm{GLRaV}=$ Grapevine leafroll associated virus .

Table 3. Transmission of Grapevine leafroll associated virus-3 (GLRaV-3) by the grape mealybug

\begin{tabular}{lcc}
\hline $\begin{array}{l}\text { Mealybugs } \\
\text { per vine }\end{array}$ & Recipient cultivar & $\begin{array}{c}\text { Virus status after 1 year } \\
\text { no. infected/no. inoculated }\end{array}$ \\
\hline Trial 1: 21-day acquisition from 'Merlot' infected with GLRaV-3' & \\
45 & Cabernet Sauvignon & $3 / 5$ \\
45 & Merlot & $1 / 1$ \\
Trial 2: mealybugs collected from colonies established on GLRaV-3-infected 'Cabernet Franc'b & $1 / 2$ \\
25 & Cabernet Sauvignon & $2 / 6$ \\
$13-25$ & Merlot & \\
\hline
\end{tabular}

${ }^{a}$ In trial 1, grape mealybugs were allowed to acquire the virus for 21 days and then allowed to transmit the virus for 42 days.

${ }^{\mathrm{b}}$ In trial 2, grape mealybugs were collected from colonies established on virus-infected vines. The grape mealybugs were allowed to transmit the virus for 53 days. Virus status of grapevines was determined by enzyme-linked immunosorbent assay. general agreement with the relative distribution of the viruses reported in other grape production areas of North America. GLRaV-3 is the most frequently encountered virus associated with leafroll disease of grapes. In Canada, GLRaV-1 and -3 were detected in 1.7 and $10.8 \%$, respectively, of wine and juice grapes (6), whereas GLRaV-1 and -3 were detected in 0 and $35.6 \%$, respectively, of wine and juice grapes in Missouri (8). A survey of juice grapes in New York revealed GLRaV3 in $26 \%$ of the vines (14).

This study also has demonstrated the ability of local populations of the grape mealybug to transmit GLRaV-3 (Table 3). Both the virus isolate and the insect vectors used in these trials originated from resident populations, demonstrating that the potential exists for virus transmission in the local setting of the Pacific Northwest. Transmission of GLRaV-3 was confirmed in 7 of 15 trials. These data are consistent with those that indicate that grape mealybug populations in California can transmit GLRaV-3 isolates originating in that area (2).

The high incidence of leafroll-associated viruses in the Pacific Northwest and the demonstrated ability of indigenous populations of grape mealybug to transmit local isolates of GLRaV-3 led to an in-depth review of certification programs. The Washington State program was established in 1976, and at that time, it was believed that there was no field transmission of leafroll disease. Therefore, no provisions for periodic retesting of registered mother blocks were instigated to ensure that infection of the vines had not occurred. The results of this study precipitated an expansion of the foundation block program to provide elite stock to nurseries. Regular sampling and testing of all registered mother vines to ensure freedom from known viruses is now a major component of the State Certification Program. The Oregon program was found to have GLRaV-infected material and has since been discontinued.

This study has provided a backdrop against which the direction of virus control programs can be more efficiently developed in the Pacific Northwest. A greatly expanded program to provide elite, virusfree propagation material to registered nurseries in the tristate region of Idaho, Oregon, and Washington has emerged as a cornerstone of virus control in this area, in part as a result of the data obtained in the study presented here.

\section{ACKNOWLEDGMENTS}

We thank Jason Lett, Janelle Barnes, and Mark Akimoff for technical assistance and the Oregon Wine Advisory Board and the Washington Wine Advisory Board for financial assistance with this project.

\section{LITERATURE CITED}

1. Converse R. H., and Martin, R. R. 1990. ELISA for plant viruses. Pages 179-196 in: Se- 
rological Methods for Detection and Identification of Viral and Bacterial Plant Pathogens. R. Hampton, E. Ball and S. DeBoer, eds. American Phytopathological Society, St. Paul, MN.

2. Golino, D. A., Sim, S. T., Gill, R., and Rowhani, A. 2002. California mealybugs can spread grapevine leafroll disease. Calif. Agric. 56:196-201.

3. Habili, N., Fazeli, C. F., and Rezaian, M. A. 1997. Identification of a cDNA clone specific to grapevine leafroll-associated virus 1 , and occurrence of the virus in Australia. Plant Pathol. 46:516-522.

4. Hancock, D., and Holler, S. 1993. Strategic Laboratory Sampling - Part 12. Popul. Med. News 6:1-8.

5. Ling, K. S., Zhu, H. Y., Drong, R. F., Slightom, J. L., McFerson, J. R., and Gonsalves, D. 1998. Nucleotide sequence of the $3^{\prime}$-terminal two-thirds of the grapevine leafroll-associated virus-3 genome reveals a typical monopartite closterovirus. J. Gen. Virol. 79:1299-1307.

6. MacKenzie, D. J., Johnson, R. C., and Warner,
C. 1996. Incidence of four important viral pathogens in Canadian vineyards. Plant Dis. 80:955-958.

7. Milkus, B. N. 2001. Incidence of four nepoviruses in Missouri vineyards. Am. J. Enol. Vitic. 52:56-57.

8. Milkus, B. N., and Goodman, R. N. 1999. A survey of Missouri vineyards for the presence of five grape viruses. Am. J. Enol. Vitic. 50:133-134.

9. Nolasco, G., Mansinho, A., Santos, M. T., Soares, C., Sequeira, Z., Sequeira, C., Correia, P. K., and Sequeira, O. A. 2000. Large scale evaluation of primers for diagnosis of rupestris stem pitting associated virus-1. Eur. J. Plant Pathol. 106:311-318.

10. Rowhani, A., Biardi, L., Johnson, R., Saldarelli, P., Zhang, Y. P., Chin, J., and Green, M. 2000. Simplified sample preparation method and one-tube RT-PCR for grapevine viruses. Extended Abstracts, XIII Meeting of ICVG:148, Adelaide, Australia.

11. Rowhani, A., Chay, C., Golino, D. A., and
Falk, B. W. 1993. Development of a polymerase chain reaction technique for the detection of grapevine fanleaf virus in grapevine tissue. Phytopathology 83:749-753.

12. Rozen, S., and Skaletsky, H. 2000. Primer3 on the WWW for general users and for biologist programmers. Pages 365-386 in: Bioinformatics Methods and Protocols: Methods in Molecular Biology. S. Krawetz and S. Misener, eds. Humana Press, Totowa, NJ.

13. Washington Agricultural Statistics Service. 2003. 2003 Washington Annual Bulletin. Wash. Agric. Stat. Serv.

14. Wilcox, W. F., Jiang, Z.-Y., and Gonsalves, D. 1998. Leafroll virus is common in cultivated American grapevines in western New York. Plant Dis. 82:1062.

15. Zhu, H. Y., Ling, K. S., Goszczynski, D. E. McFerson, J. R., and Gonsalves, D. 1998. Nucleotide sequence and genome organization of grapevine leafroll-associated virus- 2 are similar to beet yellows virus, the closterovirus type member. J. Gen. Virol. 79:1289-1298. 